УДК 546.175:504.054:628.1 (477.53)

(C) 2014

\author{
Фесенко О. Г., аспірант
}

(науковий керівник - доктор сільськогосподарських наук, професор П. В. Писаренко)

Полтавська державна аграрна академія

\title{
ХАРАКТЕРИСТИКА НІТРАТНОГО ЗАБРУДНЕННЯ ПОВЕРХНЕВИХ І ПІДЗЕМНИХ ВОД ПОЛТАВСЬКОГО РЕГІОНУ
}

\section{Рецензент - кандидат сільськогосподарських наук О. В. Міщенко}

Розлядається процес забруднення навколишнього природнього середовища нітратами, зокрема, поверхневих водних ресурсів. Зростаюча хімізація сільського господарства, передусім застосування високих доз мінеральних добрив, підсилюють напруженість у біологічному кругообізі речовин, збільшують небезпеку забруднення агроландмафтів. На основі аналітично-статистичного дослідження виявлено, щзо одним із найважливіших забруднювачів довкілля, зокрема, води у Полтавській області, є нітрати. Наведено результати досліджень поверхневих вод області на вміст нітратів, за даними Полтавського обласного державного проектно-технологічного иентру охорони родючості трунтів і якості продукиії.

Ключові слова: поверхневі води, нітрати, нітрити, ГДК (гранично допустима концентрачія), ГОСТ.

Постановка проблеми. В останні роки визначилася чітка тенденція до збільшення забруднення водних ресурсів як в Україні, так і в Полтавській області. Проблема водопостачання міст України з поверхневих джерел із кожним роком загострюється. Це пов'язано з багатьма факторами, одним із яких є антропогенний. Нерегулювання стоку великих річок вплинуло на якісний склад води, що призвело до інтенсивного розвитку та відмирання планктону й водоростей 3 утворенням токсичного мулу [12]. 3 відновленням промислового виробництва вміст мінеральних сполук азоту в басейнах багатьох річок поступово підвищується. Скиди недостатньо очищених вод 3 очисних міських споруд обумовлюють високий середній вміст сполук азоту у воді водотоку, що приймає ці стоки.

Слід зазначити, що Україна використовує для питних потреб переважно (на 70 \%) поверхневі води. Водночас 30 \% води для комунального господарства забирається 3 підземних вод. В Україні практично всі поверхневі (а в окремих регіонах і підземні води) за рівнем забруднення не відповідають вимогам санітарного законодавства на джерела водопостачання.

Щоб запобігти забрудненню вод нітратами i звести до мінімуму надходження їх у стічні води та вжити відповідних природоохоронних заходів, Полтавський обласний державний проектнотехнологічний центр охорони родючості грунтів і якості продукції проводить постійний моніторинг та оцінку якісного стану водних джерел області [8].

Аналіз основних досліджень і публікацій, у яких започатковано розв'язання проблеми. Проблеми чистої води й охорони водних екосистем стають дедалі все гострішими, поскільки стрімко посилюється вплив на природу, спричинений науково-технічним прогресом і кліматичними змінами [1].

Питання комплексної оцінки якості води вивчалося багатьма вченими не лише в Україні (В. С. Жукинський, Д. В. Закревський, В. І. Пелешенко, В. Д. Романенко, С. І. Сніжко, В. К. Хільчевський, А. П. Чернявська, А. В. Яцик), а й за кордоном (Дж. Браун, О. Труітт, Т. Харкінс). Оцінити якісно та кількісно стан ландшафтів, що знаходяться під впливом людської діяльності, досить складне завдання, поскільки він (стан) визначається багатьма факторами [9].

Особливі труднощі виникають у процесі комплексних оцінок якості вод в умовах багатоцільового використання водного об'єкта [9].

Проблема нітратного забруднення води виникла внаслідок забруднення грунтів токсичними речовинами через нераціональне використання мінеральних і органічних і добрив, хімічних засобів захисту рослин та порушення правил гігієни й санітарії у місцях життєдіяльності людини [11]. До останнього часу вважалося, що основним забруднювачем навколишнього середовища є промисловість, а також сільськогосподарське виробництво (більш безпечна галузь). Однак виявилося, що чимала частка забруднення поверхневих вод припадає й на сільське господарство, яке, в свою чергу, зростає за рахунок хімізації рослинництва [8].

Постійне нарощування об'ємів застосування пестицидів, мінеральних та органічних добрив, 


\section{СТОРІНКА МОЛОДОГО ВЧЕНОГО}

стимуляторів росту й інших агрохімікатів сільськогосподарськими підприємствами може спричинити збільшення забруднення нітратами вод сільськогосподарського призначення. Надлишок мінеральних добрив виноситься 3 поля поверхневими і підземними водами, в результаті чого низинні місця рельєфу й природні водоймища заповнюються водами 3 підвищеним вмістом мінеральних солей [4]. До забруднюючих речовин, які потрапляють у природні води, відносяться нітрати.

Нітрати - природний складовий елемент біосфери, що існував ще за багато мільйонів років до появи людини. Нітрати - це добре розчинені у воді солі азотної кислоти. В рослину вони надходять із грунту. Лише в останні десятиріччя значний ріст використання азотних добрив, а також всезростаюче надходження нітратів у навколишнє середовище 3 інших джерел, призвели до того, що навантаження нітратів оцінюється в 150-350 мг на людину за добу й продовжує повсякчас зростати [3].

Складність проблеми полягає у тому, що нітрати - основне джерело азотного живлення рослини, і в той же час надлишок цих сполук призводить до важких екологічних наслідків, що, в першу чергу, впливають на здоров'я людей i тварин. Основна небезпека надходження нітратів в організм людини пов'язана 3 виникненням метагемоглобінанемії (гемоглобін втрачає здатність переносити кисень), канцерогенних новоутворень, імунодепресивної дії, а також зниження резистенції організму до впливу мутагенних і канцерогенних агентів [3].

Однією з причин потрапляння забруднюючих речовин у поверхневі води є гноївка, що витікає 3 наземного штабеля гною, стікає по поверхні грунту, проникаючи вглиб. Внаслідок цього у грунтові води потрапляють нітрати. Джерелом забруднення довкілля є також стічні води з території тваринницьких ферм, вигульних майданчиків для тварин тощо. Екскременти тварин мінералізуються у поверхневому шарі грунту. Вивільнені компоненти гною, не поглинені рослинами (аміак, нітрати), можуть із часом звітрюватися в повітря або вимиватися у грунтові води [2].

Існує декілька методів для визначення нітратів-іонів у природних водах за стандартами ГОСТ 23268.9-78:

- колориметричний метод визначення 3 дифеніламіном. Призначений для швидкого визначення гранично допустимого рівня нітратів іонів у мінеральних водах;

- колориметричний метод визначення 3 фенолдисульфоновою кислотою. Його використовують при виникненні сумнівів щодо якості мінеральної питної лікувальної, лікувально-столової й природної столової води;

- потенціометричний метод визначення нітратіонів. Метод призначений для визначення нітратів-іонів у мінеральних питних лікувальних, лікувально-столових і природних водах [5].

Мета досліджень. Основною метою даної статті є 3'ясування (на основі літературних даних) причин потрапляння нітратів у поверхневі та підземні води Полтавської області.

Завдання досліджень: визначення вмісту нітратів у водах сільськогосподарського призначення у Полтавській області за 2010-2012 роки.

Методи дослідження. Дослідження виконувались у відповідності до існуючих нормативних актів [5-7]. Основою дослідження став потенціометричний метод визначення нітратів-іонів [5].

Результати дослідження. Проведення хімікоаналітичних досліджень здійснювалися в Полтавському обласному державному проектнотехнологічному центрі охорони родючості грунтів і якості продукції в атестованій випробувальній лабораторії, що має спеціалізовану аналітичну лабораторію, оснащену сучасними засобами вимірювальної техніки, випробувальним обладнанням.

Матеріалом для проведення досліджень були зразки води, що відбиралися в 2010-2012 роках [8].

Усього відібрана 61 проба води, в тому числі: у водосховищах - 4, водоканалі - 1, ставках -6 , річках -17 , криницях - 16, водогонах -17 .

Дослідження проб води, що проводилися у 2010 році на вміст нітратів, показали перевищення ГДК у восьми зразках води, відібраних у криницях. Так, вміст нітратів у воді, відібраній із криниці м. Глобино Глобинського району, становить 74,0 мг/л, із криниці с. Вільхуватка Кобеляцького району - 97,5 мг/л, із криниці с. Сенча Лохвицького району - 63,1 мг/л, із криниці с. Михнівці Лубенського району - 97,5 мг/л, iз криниці с. Великі Сорочинці Миргородського району - 83,2 мг/л, із криниці с. Нехвороща Новосанжарського району - 138,0 мг/л, із криниці c. Куликове Полтавського району - 90,5 мг/л та c. Степне Полтавського району - 46,5 мг/л. Тобто, фактичний вміст нітратів перевищував ГДК у $1,64,2,17,1,4,2,17,1,85,3,07,2,01,1,03$ рази відповідно.

Значно нижчий рівень нітратів виявлено в водогонах (від 1,2 до 7,1 мг/л).

Дослідження проб води за 2010 рік показали, що в Полтавській області майже не забруднені нітратами води, річок, ставків, каналу і водосхо- 


\section{СТОРІНКА МОЛОДОГО ВЧЕНОГО}

вищ, в основному в цих водоймищах вміст нітратів становив не більше 4 мг/л.

У 2011 році вміст нітратів, (із перевищенням ГДК) був у шести зразках води, відібраної у криницях. Так, вміст нітратів у воді, відібраній із криниці м. Глобино Глобинського району, становив 52,4 мг/л, із криниці с. Вільхуватка Кобеляцького району - 187,4 мг/л, із криниці с. Сенча Лохвицького району - 129,0 мг/л, із криниці с. Великі Сорочинці Миргородського району 81,2 мг/л, із криниці с. Нехвороща Новосанжарського району - 189,0 мг/л, із криниці с. Куликове Полтавського району $-123,0$ мг/л. Тобто, фактичний вміст нітратів перевищував ГДК у 1,16, 4,16, 2,87, 1,80, 4,20, 2,73 рази відповідно.

Значно нижчий рівень нітратів виявлено в водогонах (від 0,82 до 5,52 мг/л).

Дослідження проб води за 2011 рік свідчить, що в Полтавській області майже не забруднені нітратами води річок, ставків, каналу і водосховищ, в основному в цих водоймищах вміст нітратів становив не більше 7,26 мг/л.

За результатами узагальнених аналітичних даних аналізів проб води на вміст нітратів у 2012 році було виявлено перевищення гранично допустимих концентрацій (ГДК) у трьох зразках води, відібраної у криницях. Так, вміст нітратів у воді, відібраній 3 криниці с. Сенча Лохвицько горайону становив 77,1 мг/л, що в 1,7 разу вище ГДК, із криниці с. Нехвороща Новосанжарського району - 76,2 мг/л, тобто в 1,7 разу вище ГДК, із криниці с. Степне (центр) Полтавського району - 46,2 мг/л, що в 1,02 разу вище ГДК.

Значно нижчий рівень нітратів виявлено i в водогонах (від 0,27 до 11,73 мг/л).

Дослідження проб води за 2012 рік показало, що в Полтавській області нітратами води річок, ставків, каналу і водосховищ майже не забруднені.

\section{БІБЛІОГРАФІЯ}

1. Авраменко H.I. Евтрофікаційні процеси річки Ворскла / Н. І. Авраменко // Вісник Полтавської державної аграрної академії. - 2010. - №4. С. 179-181.

2. Агроекологія: Навч. посібник / О. Ф. Смаглій, А. Т. Кардашов, П. В. Литвак [та ін.]. - К. : Вища освіта, 2006. - 671 с.

3. Агроекологія: Теорія та практикум. / За ред. В. М. Писаренка. - Полтава : Інтерграфіка, 2003. $318 \mathrm{c}$.

4. Агрохімія: підручник / М. М. Городній, А. Г. Сердюк, В. А. Копілевич [та ін.]; За ред. М. М. Городнього. - К. : Вища школа., 1995. - 526 с.

5. ГОСТ 23268.9-78. Воды минеральные пить-
В основному в цих водоймищах вміст нітратів становив не більше 1,27 мг/л [10].

Гранично допустима концентрація (ГДК) нітратів у воді становить 45 мг/л [7].

\section{Висновки:}

1. Результати моніторингу поверхневих і підземних вод сільськогосподарського використання у Полтавській області за 2010-2012 роки показали, що перевищення ГДК на вміст нітратів спостерігалося тільки в кількох криницях окремих районів області й коливався від 1,03 до 3,07 мг/л у 2010 році; від 1,16 мг/л до 4,20 мг/л у 2011 році, а від 1,027 до 1,713 мг/л - у 2012 році. 3 кожним роком ці показники змінюються. Тому, вважалося б, доцільне проведення відбору проб води у криницях поквартально, щоб простежити динаміку вмісту нітратів за рік.

2. Для зменшення забруднення вод сільськогосподарського використання нітратами потрібно впроваджувати такі системи землеробства, які виключать порушення природного циклу кругообігу речовин i, в свою чергу, забезпечать безпечне нормоване використання добрив, рівномірний їх розподіл по поверхні полів, обробка схилів таким чином, аби максимально знизити поверхневий стік; застосування амонійних форм азотних добрив, які у більшій мірі фіксуються грунтом, а також використовуються грунтовою мікрофлорою.

3. Для вирішення проблеми нітратного забруднення водоносних горизонтів доцільно залучати представників центральних органів виконавчої влади, науковців, провідних фахівців водної галузі, громадські організації.

Слід постійно інформувати населення про стан води у джерелах питного водопостачання в конкретній місцевості. Лише спільними зусиллями ситуація може бути змінена на краще.

евые лечебные, лечебно-столовые и природные столовые. Методы определения нитрат-ионов. М. : Государственный комитет по стандартам. 1978. - 12 c.

6. ГОСТ 24481-80. Вода питьевая. Отбор проб. М. : Из-во стандартов, 1991. - 5 с.

7. ГОСТ 2874-82. Вода питьевая. Гигиенические требования и контроль за качеством. - М.: Из-во стандартов. - 1984. - 8 с.

8. Коваль В. В. Динаміка забруднення вод сільськогосподарського призначення нітратами в умовах Полтавської області / В. В. Коваль, В. О. Наталочка, С. К. Ткаченко [та ін.] // Вісник Полтавської державної аграрної академії. - 2011. - №2. - С. 32-36. 
9. Мосейчук $A$. A. Оцінка якості питної води в джерелах децентралізованого водопостачання Полтавської області / А. А. Мосейчук, І. А. Бойко // Вісник Полтавської державної аграрної академії. 2011. - №4. - С. 12-17.

10. Наукові звіти Полтавського центру «Облдержродючість» про проведення проектнотехнологічних робіт за 2010-2012 роки.
11. Палапа Н. В. Антропогенне навантаження та екологічні проблеми сільських селітебних територій Полтавської області / Н. В. Палапа, Г. Л. Скрипник, В. В. Рак [та ін.] // Агроекологічний журнал. - 2011. - №4. - С. 46.

12. Чи безпечна вода на Полтавщині? - Полтава: ПМЕГО «МАМА-86», 2010. - 16 с. 